\title{
10. PALYNOLOGICAL STUDY OF PALEOGENE SEDIMENTS FROM DEEP SEA DRILLING PROJECT SITES 445 AND 446, PHILIPPINE SEA
}

\author{
Shigemoto Tokunaga, Nihon Hiryo Company, Tokyo
}

\section{INTRODUCTION}

A number of palynological surveys have been made on the deep-sea sediments around the Japanese archipelago, but the samples reported here are the first to be collected from the sedimentary rocks in the ocean east of the Ryukyu island chain. Two sets of samples were analyzed, one from DSDP Site 445 and the other from Site 446 (Figure 1).

Drilling at Sites 445 and 446, on the Daito Ridge and in the Daito Basin, penetrated to depths of 892 and 629 meters below the sea floor, respectively (Figure 2). Oligocene and upper Eocene at Site 445 are composed of limestone and calcareous mudstone, and the middle Eocene is composed of mudstone and sandy mudstone. The lower middle Eocene at Site 446 consists mostly of alternations of claystone and sandstone, and the Oligocene consists of ashy clays.

A preliminary palynological study was made on samples from cores collected below $410 \mathrm{~m}$ at Site 445 and between $86 \mathrm{~m}$ and $365 \mathrm{~m}$ at Site 446 (Table 1).

\section{ANALYTICAL METHODS}

The samples were treated first with a solution of hydrofluoric and hydrochloric acids. After washing, the residue was separated by a solution of zinc bromide with a specific gravity of 2.0 .

Acetic acid was added after a second washing, and the final residue was treated with a 10-percent solution of potassium hydroxide. This residue was mounted in glycerin jelly.

Identification of the fossil pollen and spores was made with a biological microscope at magnifications of $\times 600$ and $\times 1000$.

\section{RESULTS}

Pollen and spores generally were very rare in the calcareous rocks at Sites $\mathbf{4 4 5}$ and $\mathbf{4 4 6}$. In contrast, pollen and spores were common in the middle-Eocene mudstone. The most common taxa from the middle Eocene at Site 445 are:

\section{Coniferae}

Pinuspollenites sp. (diploxylon type)

Sequoiapollenites sp.

Taxodiaceaepollenites spp.

Sciadopityspollenites $\mathrm{sp}$.

Podocarpites? sp.

Classopollis taiwanensis Huang
Inaperturopollenites pseudodubius Takahashi

Monocolpopollenites sp. cf. M. kyushuensis Tak. (Palmae or Ginkgo)

Dicotyledonae

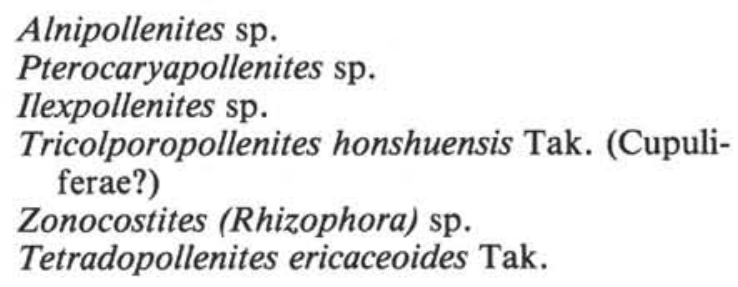

Alnipollenites sp.

Pterocaryapollenites sp.

Ilexpollenites $\mathrm{sp}$.

Tricolporopollenites honshuensis Tak. (Cupuliferae?)

Zonocostites (Rhizophora) sp.

Tetradopollenites ericaceoides Tak.

Monocotyledonae

Palmaepollenites sp.

Monoporopollenites sp. (cf. Gramineae)

Filicinae

Verrucatosporites verrucatus Tak.

Polypodiaesporites venustus $\mathrm{H}$.

cf. Leiotriletes taiwanensis $\mathrm{H}$.

Leiotriletes obovatus $\mathrm{H}$.

Concavisporites karatsuensis Tak. (cf. Gleicheniaceae)

Punctatisporites sp.

Lygodioisporites sp.

Deltoidospora sp.

The Oligocene sediments between 82 and $139 \mathrm{~m}$ at Site 446 are composed of clay with ash, and they contain almost no pollen or spores. The middle-Eocene sediments below these were dark-gray claystone and muddy sandstone which contain many pollen grains and spores. The most common taxa in these assemblages are:

\section{Coniferae}

Ephedripites sp.

Sequoiapollenites $\mathrm{sp}$.

Taxodiaceaepollenites spp.

Dicotyledonae

Alnipollenites sp.

Castaneapollenites sp.

Tricolporopollenites coryloides Pf.

Tricolpopollenites reticulatus Tak. 


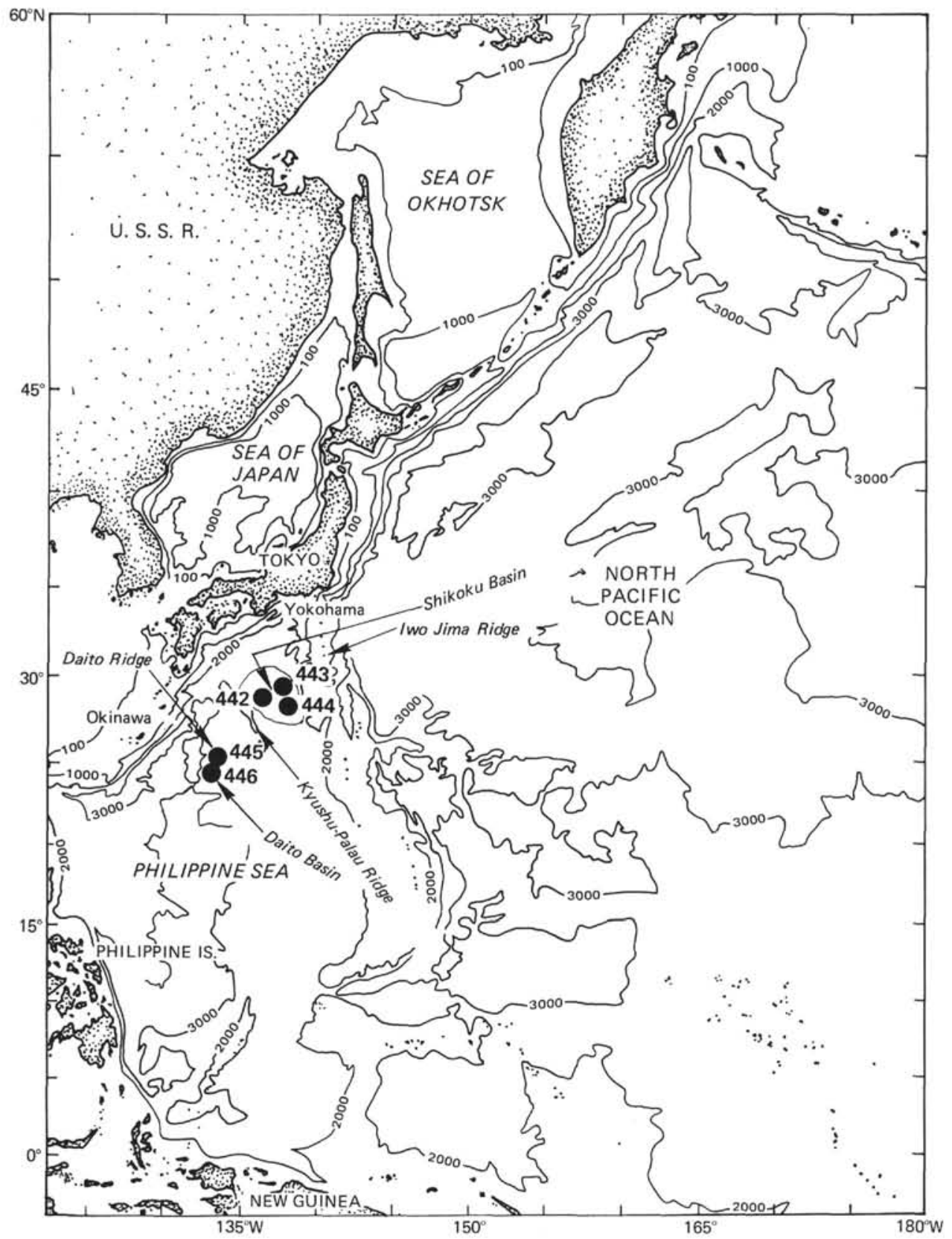

Figure 1. Locations of DSDP Sites 445 and 446.

Filicinae

Osmundacidites sp.

Verrucatosporites $\mathrm{sp}$.

Leiotriletes $\mathrm{sp}$.

Polypodiacaeasporites sp.

Laevigatosporites sp.

Among the pollen and spores of the middle Eocene of the two sites, Taxodiaceaepollenites, Sciadopityspollenites, and Sequoiapollenites indicate a temperate climate;
Sequoiapollenites is common. Palmaepollenites, Ephedripites, and Zonocostites (Rhizophora) are subtropical and tropical elements. Osmundacidites and Lygodioisporites are generally indicators of warm-temperate conditions; these spores are somewhat larger than those of the same genera found in northern Kyushu, Japan.

The Tricolpate-type pollen commonly found in the Eocene sediments of northern Kyushu are rather rare in the Eocene sediments from the Daito Ridge.

From these preliminary results, the middle-Eocene climate of the Daito Ridge area is presumed to have been warm-temperate. 


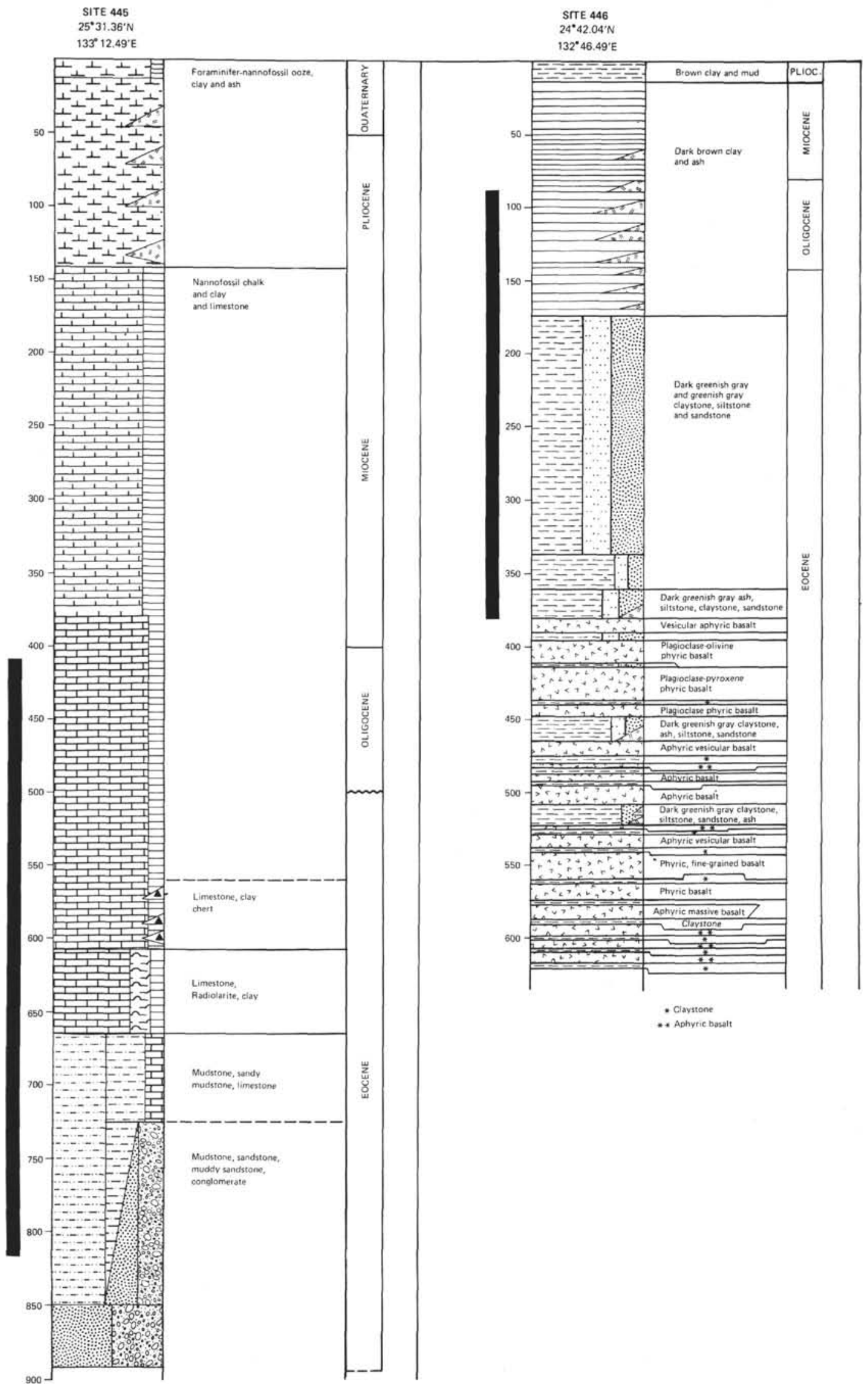

Figure 2. Stratigraphy of DSDP Sites 445 and 446. (Black bar shows sampled interval.) 
TABLE 1

Palynological Samples, DSDP Sites 445 and 446

\begin{tabular}{ccc}
\hline & $\begin{array}{c}\text { Sub-bottom } \\
\text { Depth } \\
\text { (interval in cm) }\end{array}$ & Age \\
\hline $445-46-4,95-96$ & $430.45-430.46$ & \\
$49-2,102-104$ & $457.02-457.04$ & Oligocene \\
$52-2,16-18$ & $488.16-488.18$ & \\
$56-2,50-52$ & $523.50-523.52$ & \\
\hline $60-4,13-15$ & $564.13-564.15$ & Late Eocene \\
$62-6,63-65$ & $586.63-586.65$ & \\
\hline $66-4,16-18$ & $621.16-621.18$ & \\
$68-1,44-46$ & $635.94-634.96$ & \\
$69-4,52-54$ & $650.02-650.04$ & \\
$71-4,13-15$ & $668.63-668.65$ & \\
$74-4,46-48$ & $697.46-697.48$ & \\
$75-4,109-111$ & $707.59-707.61$ & \\
$77-4,144-146$ & $726.44-726.44$ & \\
$79-5,51-53$ & $746.51-746.53$ & Middle Eocene \\
$80-4,64-66$ & $754.14-754.16$ & \\
$82-4,70-72$ & $773.70-773.72$ & \\
$83-4,76-78$ & $783.26-783.28$ & \\
$85-4,94-96$ & $802.44-802.46$ & \\
$87-4,40-42$ & $820.90-820.92$ & \\
$88-3,58-60$ & $829.08-829.10$ & \\
$91-5,56-58$ & $860.56-860.58$ & \\
$94-4,45-47$ & $887.45-887.47$ & \\
\hline \hline $446-10-4,81-83$ & $82.81-82.83$ & \\
$13-4,115-117$ & $111.65-111.67$ & Oligocene \\
$16-4,38-40$ & $139.38-139.40$ & \\
\hline $20-1,70-71$ & $173.20-173.21$ & \\
$24-4,87-89$ & $215.87-215.89$ & \\
$27-2,115-117$ & $241.55-241.57$ & \\
$30-4,74-76$ & $272.74-272.76$ & Middle Eocene \\
$34-3,40-42$ & $308.90-308.92$ & \\
$38-3,132-134$ & $347.82-347.84$ & \\
$41-3,120-122$ & $375.70-375.72$ & \\
\hline & & \\
\hline
\end{tabular}

